\begin{abstract}
Iranica
Abstracta Iranica Revue bibliographique pour le domaine irano-aryen

Volume 32-33 | 2013

Comptes rendus des publications de 2009-2010
\end{abstract}

\title{
Kenneth Lizzio. Ritual and Charisma in Naqshbandi Sufi Mysticism
}

\section{Mauro Valdinoci}

\section{(2) OpenEdition \\ 1 Journals}

\section{Electronic version}

URL: http://journals.openedition.org/abstractairanica/40635

DOI: 10.4000/abstractairanica.40635

ISSN: 1961-960X

Publisher:

CNRS (UMR 7528 Mondes iraniens et indiens), Éditions de l'IFRI

\section{Printed version}

Date of publication: 1 December 2013

ISSN: 0240-8910

\section{Electronic reference}

Mauro Valdinoci, « Kenneth Lizzio. Ritual and Charisma in Naqshbandi Sufi Mysticism », Abstracta Iranica [Online], Volume 32-33 | 2013, document 279, Online since 01 July 2016, connection on 03 October 2020. URL : http://journals.openedition.org/abstractairanica/40635; DOI : https://doi.org/10.4000/ abstractairanica.40635

This text was automatically generated on 3 October 2020 .

Tous droits réservés 


\title{
Kenneth Lizzio. Ritual and Charisma in Naqshbandi Sufi Mysticism
}

\author{
Mauro Valdinoci
}

\section{REFERENCES}

Kenneth Lizzio. « Ritual and Charisma in Naqshbandi Sufi Mysticism ». Anpere

(Anthropological Perspectives on Religion), published on-line 21-02-2007, p. 1-37.

1 This ethnological study of a branch of the Naqšbandiyya Mujaddidiyya order based in Pakistan's tribal area combines ethnological fieldwork with a historical and textual analysis that evinces recent theories in transpersonal psychology. Suggestive of an original approach to the study of Sufism, its chief aim is to correct the anthropologist's tendency to focus exclusively on the social, political and economical aspects of Sufi orders while neglecting the esoteric and spiritual ones. The author makes a strong case for taking the cultivation of spiritual life more seriously in the anthropology of Sufism. By providing a detailed description of Naqšbandī cosmology, rituals and spiritual exercises, this article refines the description of the characteristics of a Sufi master's charisma and spiritual authority. Referring to Naqšbandī doctrine and practices and to testimonies from practitioners, the author argues that the order's raison d'etre is to cultivate the deep structures of human consciousness. The text ends with a call for a new theoretical framework, a "transcendental anthropology" that would be better suited for explaining spiritual issues and practices. 


\section{AUTHORS}

\section{MAURO VALDINOCI}

University of Modena and Reggio Emilia 